\title{
Radiological Monitoring of Hip Replacements in Sickle Cell Disease Patients: Report of 31 Cases
}

\author{
Zouzou Ange Eric ${ }^{1,2 *}$, Gnaoulé Debato Tina ${ }^{1,2}$, Kouassi Bonfils ${ }^{1,3}$, N'dja Ange Patrick1,2, \\ Kanga Alexis $^{1,2}$, Vanga Marius ${ }^{3}$, Konan Alexis ${ }^{1,2}$, Gbazi Gogoua Casimir ${ }^{1,2}$ \\ ${ }^{1}$ Faculty of Medical Sciences of Abidjan, Felix Houphouet-Boigny University of Abidjan, Abidjan, Côte d'Ivoire \\ ${ }^{2}$ Department of Radiology, University Hospital of Cocody, Abidjan, Côte d'Ivoire \\ ${ }^{3}$ Department of Radiology, University Hospital of Bouaké, Bouaké, Cote d'Ivoire \\ Email: ^aegzouzou@gmail.com
}

How to cite this paper: Eric, Z.A., Tina, G.D., Bonfils, K., Patrick, N.A., Alexis, K., Marius, V., Alexis, K. and Casimir, G.G. (2016) Radiological Monitoring of Hip Replacements in Sickle Cell Disease Patients: Report of 31 Cases. Open Journal of Orthopedics, 6, 305-310.

http://dx.doi.org/10.4236/ojo.2016.610039

Received: August 1, 2016

Accepted: September 27, 2016

Published: September 30, 2016

Copyright $\odot 2016$ by authors and Scientific Research Publishing Inc. This work is licensed under the Creative Commons Attribution International License (CC BY 4.0).

http://creativecommons.org/licenses/by/4.0/ (c) (i) Open Access

\begin{abstract}
Aim: The objective of the study was to report the progressive complications of hip joint disease in a population of sickle cell. Materials and Methods: A descriptive and retrospective study from 2002 to 2008: A case of 31 sickle cell subjects having presented an advanced osteonecrosis of the femoral head. All the patients benefited from an arthroplasty in adulthood with a radiographic monitoring in immediate post operative before and after one year. The sickle cell subjects were compared to a non sickle cell control group of 37 patients according to the same criteria. The analysis had included considerations of the environment and the position of the prosthetic parts, as well as additional modifications. The types of complications and the moment at which they occur were indexed and analyzed using a statistical test of FISHER with a threshold of significance level $p<0.05$. Results: The average age of sickle cell patients was 35 years and non sickle cell disease sufferers, 51, with a male predominance. Indications for surgery were dominated by coxarthroses, 31 cases (100\%) in sickle cell disease sufferers and 17 cases (46\%) among the control group. All our patients underwent a radiological control in the immediate postoperative. They were fewer between 6 months and 1 year (19\%). The immediate complications were dominated by fractures 2 cases in non sickle cell disease sufferers. The complications before one year were marked by a predominance of dislocation, 3 cases in the non sickle cell population against 2 cases in sickle cell population. The loosening were the most observed complications in both populations after a year and more ( 5 cases in sickle cell disease sufferers and 6 cases in non sickle cell disease sufferers). Conclusion: The evolutionary complications of joint replacements in sickle cell subjects are not more frequent than in non sickle cell subjects.
\end{abstract}

\section{Keywords}

Arthroplasty of Hips, Sickle, Radiology 


\section{Introduction}

Sickle cell disease, the most frequent hemoglobinopathy in the world, occurs primarily in black patients and populations around the Mediterranean. It is about a genetic disease characterized by the presence of S hemoglobin, transmitted according to the Mendelian autosomal codominant way.

The sickle cell disease diagnosis is due to the hemoglobin electrophoresis which makes it possible to differentiate the abnormal hemoglobin: AS, SS, SC, S beta thalassemia [1]. Sickle cell disease affects approximately $10 \%$ of the population of Côte d'Ivoire. It is a provider of hip disease in young patients among $20 \%-32 \%$ [2] of sickle cell disease sufferers. The management of these hip diseases often requires the completion of a joint replacement. The environment, the relative youth of these patients and the quality of bone pose the problem of the feasibility and the survival of hip implants [3]. Finding the evolutionary complications and evaluating the morbidity of hip replacements in sickle cell patients are the objectives of this work.

\section{Materials and Methods}

This was a retrospective study that took place in the service of radiology and trauma surgery of the International Polyclinic Sainte Anne Mairie (PISAM).

We collected 31 cases of sickle cell patients known since childhood, who presented the court monitoring their sickle cell disease advanced arthropathy of the femoral head who underwent hip replacement between 2002 and 2008.

The inclusion criteria: about age greater than or equal to 21 years, who has made control of X-rays; the average age of patients was 35 years with extremes of 25 and 45 .

The exclusion criteria: about age below 21 years, or adult subject who did not receive all the postoperative radiographic inspection.

In order to assess the morbidity of this intervention in the sickle cell patient, we studied a control population of 37 adult patients without sickle cell disease and who received a hip replacement in the same structure during the same period.

The type of prosthesis has not been taken into account in the development of complications.

The average age of the pilot population was 51 years, with extremes ranging from 40 to 92 years.

The indications in the pilot population were represented by coxarthroses 17 cases (46\%), femoral neck fractures 18 cases (48.6\%) and dislocations 2 cases (5.4\%).

The total hip prosthesis was the most used in our patients in $68 \%$ of the cases followed by cervical-cranial prosthetics $29 \%$ of the cases and in $3 \%$ of the cases, an intermediate prosthesis.

The cement was the method of attachment used in almost all the cases (95\%).

Face basin impacts, 3/4 wing and shutters were carried out in each immediate postoperative radiological control at 6 months, 12 months and annually.

The monitoring time was 10 years for the first and last patient operated.

The analysis of the radiological materials had comprised: 
1) The analysis of the environment, the position and integrity of the prosthetic pieces

2) The assessment of the aspect of the femur and the acetabulum,

3) The study of soft tissue and pelvic excavation.

The type of acute or chronic complications and their moment of occurrence have been identified in each population.

The statistical analysis had been carried out using the comparative test of Fischer with a significance level $\mathrm{P}<0.05$.

\section{Results}

\section{1) The radiological monitoring}

All our patients had received a radiation monitoring in the immediate post-operative. They were $43 \%$ to be present at the 6 months control. They were fewer between 6 months and 1 year (19\%) and (24\%) after 1 year.

\section{2) The immediate complications}

They were observed in the immediate postoperative period and before three (03) months. They were dominated by fractures; 02 cases observed only in non-sickle cell disease sufferers. (Figure 1). A case of dislocation was diagnosed in each population. The presence of cement was highlighted in the pelvic cavity of a sickle cell patient.

\section{3) Complications at 6 months}

There were more dislocations ( 03 cases) and fractures ( 03 cases) in the non sickle cell population (Figure 2 ) than in the sickle cell population with only 02 cases of dislocations (Table 1).

\section{4) Complications after 1 Year and More}

The loosening were the most observed complications in the two populations: 05 cases in sickle cell disease sufferers and 06 cases in non-sickle cell population (Figure 3). Among the loosenings, one (01) was septic in each population (Table 2).

Table 1. Distribution of complications in 2 populations before 1 year.

\begin{tabular}{cccc}
\hline Complications & Sickle cell patients & Non sickle cell patients & P \\
\hline Fracture & 00 & 03 & 0.155 (NS) \\
Dislocation & 02 & 03 & 0.584 (NS) \\
Femoral loosening & 01 & 00 & 0.0455 (NS) \\
Ossification on Prosthesis & 01 & 00 & 0.455 (NS) \\
\hline
\end{tabular}

Table 2. Distribution of complications after 1 year.

\begin{tabular}{cccc}
\hline Complications & Sickle cell patients & Non sickle cell patients & $\mathrm{P}$ \\
\hline Fractures & 00 & 01 & 0.544 (NS) \\
Dislocations & 01 & 01 & 0.707 (NS) \\
Aseptic loosening & 04 & 05 & 0.614 (NS) \\
Septic loosening & 01 & 01 & 0.707 (NS \\
Ossification on Prosthesis & 01 & 01 & 0.707 (NS) \\
\hline
\end{tabular}




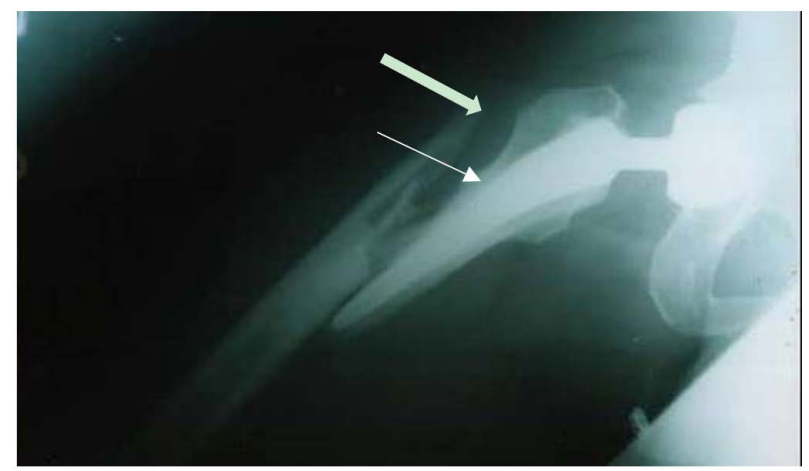

Figure 1. Pelvic radiograph showing a fracture on prosthesis (arrow indication).

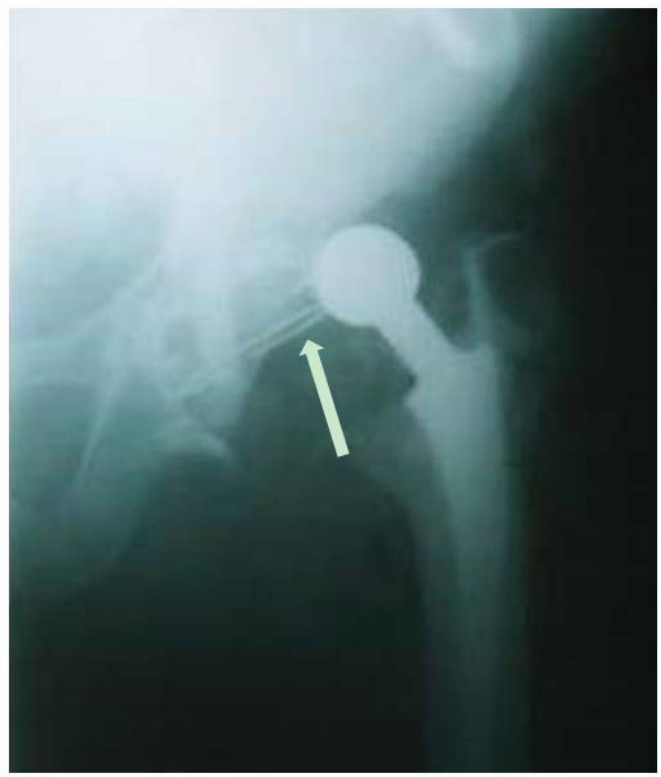

Figure 2. Pelvic radiograph showing a prosthetic dislocation (arrow indication).

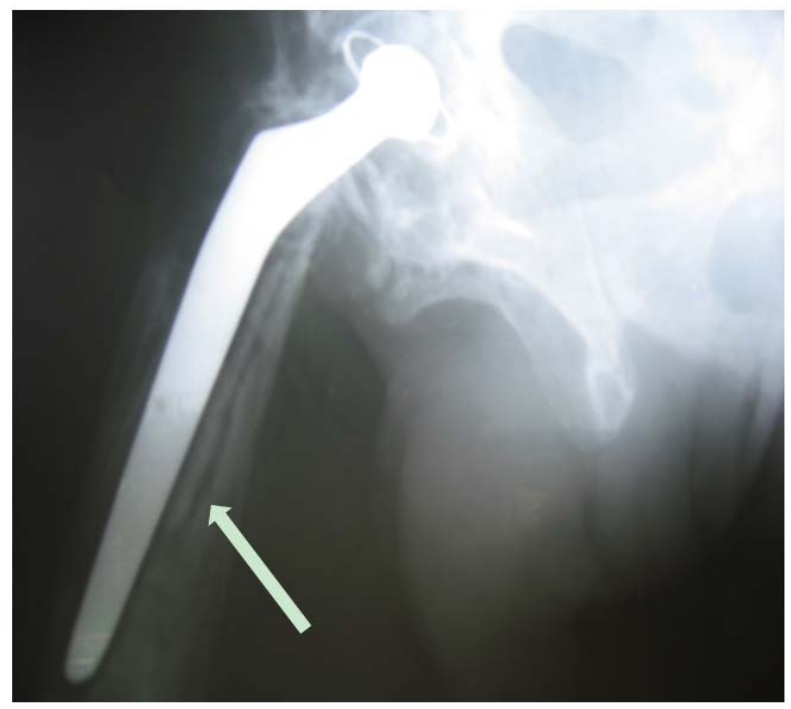

Figure 3. Femoral prosthetic loosening (arrow indication). 


\section{Discussion}

\subsection{The Quality of the Radiological Monitoring}

If the immediate postoperative period radiographies were made among all our patients on the other hand, the attendance rate of the unit of Radiology declined during the subsequent radiological monitoring. They were less than half (43\%) at 6 months, 19\% between 6 months and 1 year and then $24 \%$ after 1 year.

The low level of attendance of the Radiology unit by these patients during the monitoring had already been revealed by FOFANA [4] in a similar study.

In contrast, the observance of radiation monitoring was better in the western series with an overall estimated attendance rates of $75 \%-85 \%$ [5] [6].

Our patients only attended the hospital when the operated hip became painful. They should be informed about the importance of the radiological monitoring of replacements and that any poor adherence thereof compromises the survival of the prostheses.

Moreover the patients' lack of financial means and the absence of health insurance in our country did not favor a good radiological monitoring and this describes the African specificity.

\subsection{The Radiation Monitoring}

The immediate complications were dominated by fractures and dislocations also more frequent in non-sickle cell population as well as in sickle one. They are not therefore only related to the sickle cell environment.

The causes according SEDEL [7] are of several types. There may be technical errors caused by the excessive milling of the bone pieces in connection to inadequate prostheses, the osteoporosis in the old subject, and the mechanical constraints being exerted on the prosthesis in the young patient.

The loosening with $13.50 \%$ in non-sickle cell population and $12.90 \%$ in the sickle cell population constituted the most frequent chronic complications. The statistical comparison of this complication was not significant $(\mathrm{P}=1)$.

In addition, this complication was not more common among us than in Western series in which loosening up $15 \%$ to $20 \%$ of complications [8] [9].

We observed in our study a case of septic loosening in each population that occurred in an immune-compromised environment.

\subsection{Conclusions}

The progressive complications of joint replacement in a sickle cell environment were not more frequent than in a non sickle subject.

The high cost of prosthetics in our context remains an obstacle to the practice of joint replacements in sickle cell patients. It remains technically difficult requiring thus a perpetual monitoring.

\section{Conflict of Interest}

The authors report no conflict of interest. 


\section{References}

[1] Catonné, Y., Mukisi Mukasa, M., Rouvillain, J.L. and Ribeyre, D. (2004) Osteo-Articular Manifestations of Sickle Cell Disease. Orthopedic Mastery, 135.

[2] Tageja, N., Racovan, M., Valent, J., et al. (2010) Myonecrosis in Sickle Cell Anemia-Overlooked and Underdiagnosed. Case Reports in Medicine, 659031. http://dx.doi.org/10.1155/2010/659031

[3] Doubovetzky, J. (1996) Main Indications and Monitoring Hip Prostheses. Prescribe, 16, 781-787.

[4] Fofana, M. (2000) Radiation Monitoring of the Hip Prosthesis. Th. Med, 2516.

[5] Mouel, S., Allain, J. and Goutallier, D. (1998) Actuarial Report to 10 Years in a Cohort of 156 Total Hip Replacements with Cemented Frictional Torque Chir Orthop Allumine/Polyéthylène. Rev Mainten Appar Word, 84, 338-345.

[6] Cyteval, C., Gagneux, E., Sarrabère, M.P., Benis, J., Cottin, A., Maury, P. and Taourel, P. (2002) Imaging of Complications of Total Hip Prostheses. Journal of Radiology, 83, 115121.

[7] Sedel, L., Christel, P., Kerboull, L. and Witwoe, J. (1990) Total Hip Replacement before Age 50: Interest Ceramic Materials. Rev Rhum, 57, 605-611.

[8] Thevenin, F., Campagna, R., Guerini, H., Poittevin, X., Feydy, A., Drape, J.-L. and Chevrot, A. (2007) Imaging of Hip Prostheses. EMC, Diagnostic Radiology-Normal Skeleton-Neuroradiology-Musculoskeletal, 31-314-A-10-2007.

[9] Boisgard, S., Bouillet, B., Descamps, S. and Levai, J.P. (2012) Medical and Surgical Complications in Total Hip Arthroplasty e-Memories of the National Academy of Surgery. 11, 6063.

Submit or recommend next manuscript to SCIRP and we will provide best service for you:

Accepting pre-submission inquiries through Email, Facebook, LinkedIn, Twitter, etc. A wide selection of journals (inclusive of 9 subjects, more than 200 journals)

Providing 24-hour high-quality service

User-friendly online submission system

Fair and swift peer-review system

Efficient typesetting and proofreading procedure

Display of the result of downloads and visits, as well as the number of cited articles

Maximum dissemination of your research work

Submit your manuscript at: http://papersubmission.scirp.org/

Or contact ojo@scirp.org 